\title{
Application of Fuzzy logic for the analysis of the pandemic (COVID-19), if there was no social isolation
}

\section{Aplicação da lógica Fuzzy para análise da pandemia (COVID-19), se não houver isolamento social}

\author{
Ana Paula Silva Artur, Bruna Maria Paterline Novais Abreu, Leandro José Pedrosa de \\ Lima Oliveira, Edson Romano Nucci
}

Como citar este artigo:

ARTUR, ANA PAULA S.; ABREU, BRUNA M. P. N.: OLIVEIRA,

LEANDRO J. P. L.; NUCCl, EDSON

R.; Application of Fuzzy logic for

the analysis of the pandemic

(COVID-19), if there was no social

isolation. Revista Saúde (Sta.

Maria). 2020; 46 (2)

\section{Autor correspondente:}

Nome: Ana Paula Silva Artur

E-mail: anaps.artur@gmail.com

Telefone: (3 I) 99858-4284

Formação Profissional: Master of

Science in Chemical Engineering,

Federal University of Sao João Del

Rei (UFSJ), São João Del Rei, MC,

Brazil.

Filiação Institucional: UFSJ

Endereco para correspondência:

Rua: Begônia ñ:362

Bairro: Belvedere

Cidade: Congonhas

Estado: Minas Gerais

CEP: $36412-066$

Data de Submissão:

06/03/2020

Data de aceite:

23/07/2020

Conflito de Interesse: Não há conflito de interesse

\section{(cc) $\mathrm{B} Y-\mathrm{NC}-\mathrm{ND}$}

\section{ABSTRACT}

At the end of 2019 a respiratory syndrome hit the population of China. Studies have found that this contamination was caused by the SARS-CoV-2 virus. By 2020, the coronavirus contamination spread around the world, generating a pandemic that has impacted the health of millions of people. Looking for methods to understand the spread of the pandemic is fundamental to define prevention and containment measures, the use of computer software provide a view of the evolution of contamination. Fuzzy logic is a logical technique based on Fuzzy set theory and, using this theory, it is possible to deal with uncertainties, approximate reasoning, vague and ambiguous terms, which classical logic does not allow. In order to model the system, you must define the input and output variables, write the rule sets and insert the pertinence functions with the graph type to be used. For this work, the modeling was performed having two variables in the input and each variable presented three pertinence functions, and one output variable that also had three pertinence functions and nine rules. The results obtained were coherent and demonstrated graphically what would happen to a susceptible group if they were exposed without any form of isolation or protection.

KEYWORDS: Coronavirus; SARS-CoV-2; pandemic; Fuzzy logic.

\section{RESUMO}

No final de 2019 uma síndrome respiratória atingiu a população da China, mais precisamente na província de Wuhan, com 11 milhões de habitantes. Estudos descobriram que a contaminação era provocada pelo vírus SARS-CoV-2. Entretanto, no início de 2020 a contaminação pelo coronavírus se espalhou ao redor de todo o mundo, gerando uma pandemia que vem impactando na saúde de milhões de pessoas. Procurar métodos para entender a propagação da pandemia é fundamental visando definir medidas de prevenção e contenção. Deste modo, o uso de softwares proporciona uma visão da evolução da contaminação. A Lógica Fuzzy é uma técnica lógica baseada na teoria dos conjuntos fuzzy e é possível lidar com incertezas, raciocínio aproximado, termos vagos e ambíguos, o que a lógica clássica não permite. Para modelar o sistema é necessário definir as varáveis de entrada e saída, escrever conjunto de regras e inserir as funções de pertinência com o tipo de gráfico a ser utilizado. Neste trabalho a modelagem foi realizada com duas variáveis na entrada sendo que cada variável apresenta três funções de pertinência, uma variável de saída que também possui três funções de pertinências com um total de nove regras geradas. Os resultados obtidos foram coerentes e demonstram de forma gráfica o que aconteceria a um grupo susceptível caso sejam expostos sem nenhuma forma de isolamento ou proteção.

PALAVRAS-CHAVE: Coronavírus; SARS-CoV-2; pandemia; lógica Fuzzy. 


\section{INTRODUCTION}

COVID 19 is a respiratory epidemic caused by a virus of the coronaviridae family, the SARS-CoV-2. The disease can range from mild cases such as a flu-like respiratory syndrome to severe cases that the infected manifest respiratory insufficiency and may die (PRATA; RODRIGUES; BERMEJO, 2020). Studies report that SARS-CoV-2 has spread with high aggressivity and speed to several countries, generating a global crisis, classifies by the World Health Organization (WHO) as a pandemic (BUKHARI; JAMEEL, 2020) .

The use of computer software provides a general view on what may happen, one of the models most commonly used by epidemiologists is the SIR/SIRS system, which was created by the Scottish researchers Anderson Gray McKendrick and William Ogilvy Kermack and their model presents a compartmentalized structure on which people are distributed according to their "state" related to the disease and on which interconnected groups exchange individuals (FARIAS, 2017). However, this model has two difficulties: the determination of the parameters (variability), because they are only obtained through statistical studies of the epidemics on certain regions and this information, although being essential for the prediction, may require a considerable amount of time to be gathered; and the partial ignorance, which results from systematic measurement errors or from unknowing parts of the considered process (subjectivity), but statistical tests usually cannot comprise the ignorance and the subjectivity issues, in order to solve them, Fuzzy Logic Theory can be used (ALVARENGA, 2008) (ORTEGA, 2001). The Fuzzy Logic technique provides answers, requires less information and, through a set of rules (describing linguistics variables) and functions of pertinence, is able to provide an overview on epidemiologic models.

Fuzzy logic is logic based on Fuzzy set theory, unlike normal logic that always presents an exact value, this one provides the possibility of approximate reasoning, that is, Fuzzy logic uses the idea that all things admit degrees of pertinence, consequently it models the sense of words, decision making or common sense, being interpreted as a process of composition of nebulous relations (RIGNEL; CHENCI; LUCAS, 2011). The advantage of using this technique is due to its ability to deal with uncertainties, approximate reasoning, vague and ambiguous terms, which classical logic does not allow and for which SIR model is not adequate. Precisely because of these characteristics this technique has become one of high importance in the Artificial Intelligence field (ALVIM; NAU; OLIVEIRA, 2019).

Fuzzy logic is logic based on Fuzzy set theory, unlike normal logic that always presents an exact value, this one provides the possibility of approximate reasoning, that is, Fuzzy logic uses the idea that all things admit degrees of pertinence, consequently it models the sense of words, decision making or common sense, being interpreted as a process of composition of nebulous relations (RIGNEL; CHENCI; LUCAS, 2011). The advantage of using this technique is due to its ability to deal with uncertainties, approximate reasoning, vague and ambiguous terms, which classical logic does 
not allow. Precisely because of these characteristics this technique has become one of high importance in the Artificial Intelligence field. However, Fuzzy logic presents as a disadvantage the stability of the systems, because they are not able to adapt to extremely dynamic contexts, on which there are difficulty in defining good pertinence functions and Fuzzy rules, with these being the principle for a good modeling of this technique, another disadvantage is the validation or verification of a Fuzzy expert system (MARRO et al., 2000) (SANTOS, 2015).

In order to apply this simulation, one must write a set of rules that has the function of describing the behavior of the process as a function of linguistic variables, which provided the behavior modification. The pertinence functions are constituted and the rule set is processed according to the defined values of the variables involved. The model is tested to verify if it is compatible to the real process or not. If the response generated by the model does not correspond to the real process, changes must be made on the number of rules or on the number of antecedents (GOMIDE; GUDWIN; TANSCHEIT, 1995) (SANTOS, 2015). The pertinence functions can be represented in different formats, such as: triangular, trapezoidal, gaussian and singleton (SILVA, 2013). The most commonly used pertinence functions are triangular and trapezoidal, this is because they provide a better suitability, as the idea of regions of pertinence for both can be total, average and null and this conditioning is more objective than the specifications related to the parameters of the Gaussian and Singleton functions (FERNANDES, 2005).

The Mamdani and the Takagi-Sugeno models are the main Fuzzy models. The main difference between them is that in Mamdani systems, both the antecedent and the consequent are expressed by linguistic terms. On the other hand, in Takagi-Sugeno systems only the antecedent is expressed by linguistic terms and the consequent is expressed by functional terms, however, the rules need to be weighted. Because the Mamdani inference model is more intuitive than Takagi-Sugeno, it has higher applicability (MELO, 2009) and (SANTOS, 2015).

To fulfill the Fuzzy, it is needed to choose, after deciding the model to be used, the method of defuzzification. For a Mamdani model, the defuzzification of a cloudy set of output for a single value can be performed by some methods, such as: centroid, bisector, average of the maximums, first of the maximums and the last of the maximums. For a Sugeno model, defuzzification is done by the weighted average or the weighted sum of the linear and constant functions (LIMA, 2016). The method with greatest applicability for the Mamdani model is the centroid one, which was developed by Sugeno in 1985. This is the most used technique due to it being highly accurate, having as solution the abscissa of the center of gravity (LIMA, 2016) and (SANTOS, 2017). If the centroid method cannot be applied, the method of the average of the maximums is chosen, because it consists of a derivation of the center of gravity method (centroid) and it calculates the average between the two extreme elements in the universe that correspond to the highest values of the pertinence function (GAVIÃO; BRITO; LIMA, 2015), (MALAMAN; AMORIM, 2017) and (LEEKWIJCK; KERRE, 1999). 
With the unrestrained advance of the pandemic, different studies have been conducted with statistical models and modeling being used to examine epidemiological data (SARKODIE; OWUSU, 2020). The goal of the present study was to demonstrate through Fuzzy logic what could happen to a susceptible group exposed to SARS-CoV-2 without isolation or any mean of protection.

\section{METHODS}

In order to model a Fuzzy system, it is necessary to describe its behavior, consequently defining which physical and linguistic variables will be used (input and output variables). Next, these variables receive a set of linguistic terms, then a set of rules is written and the functions of pertinence are inserted, resulting in the graph of pertinence. Later, all this information will be used to create a tridimensional graph with the answers of the model.

In the present study, modelling was implemented on the Scilab software. First of all, the linguistic variables (two input and one output variables) were inserted, they correspond to a variable that has as value a diffuse number or that can be represented by a linguistic term. Later, the linguistic terms were also inserted. In this model, the terms used were "low", "moderate" and "high" and they were used for the input and the output variables. Then the functions of pertinence $(\mu)$ were inserted, these functions represent the degree of compatibility between the element and the concept expressed (which can be triangular, trapezoidal or gaussian). The functions of pertinence may have one single form or a mixed one, this being the chosen form for this study, because of it having a simple formation and good computational efficiency, besides, the mixed form function of pertinence is recommended for models working real time, like epidemiologic models, this occurs because this model has more intuitive total, average and null regions of pertinence than the specification of modal value or dispersion, associated with the project of Gaussian functions (ARAUJO, 2009) (PIMENTA, 2009).

This Fuzzy modeling is shown on Figure 1, which shows the flowchart of the linguistic variables, linguistic terms and function of pertinence. In order to provide a better understanding, a graphic representation of the flowchart is represented below the flowchart. The graphs of pertinence generated by the Scilab software can be found in the appendix. 
Figure 1: (a) Variables with their respective Pertinence Functions and the chart type for Fuzzy; (b). Representação gráfica do Fluxograma (a);

(a)

$1^{0}$

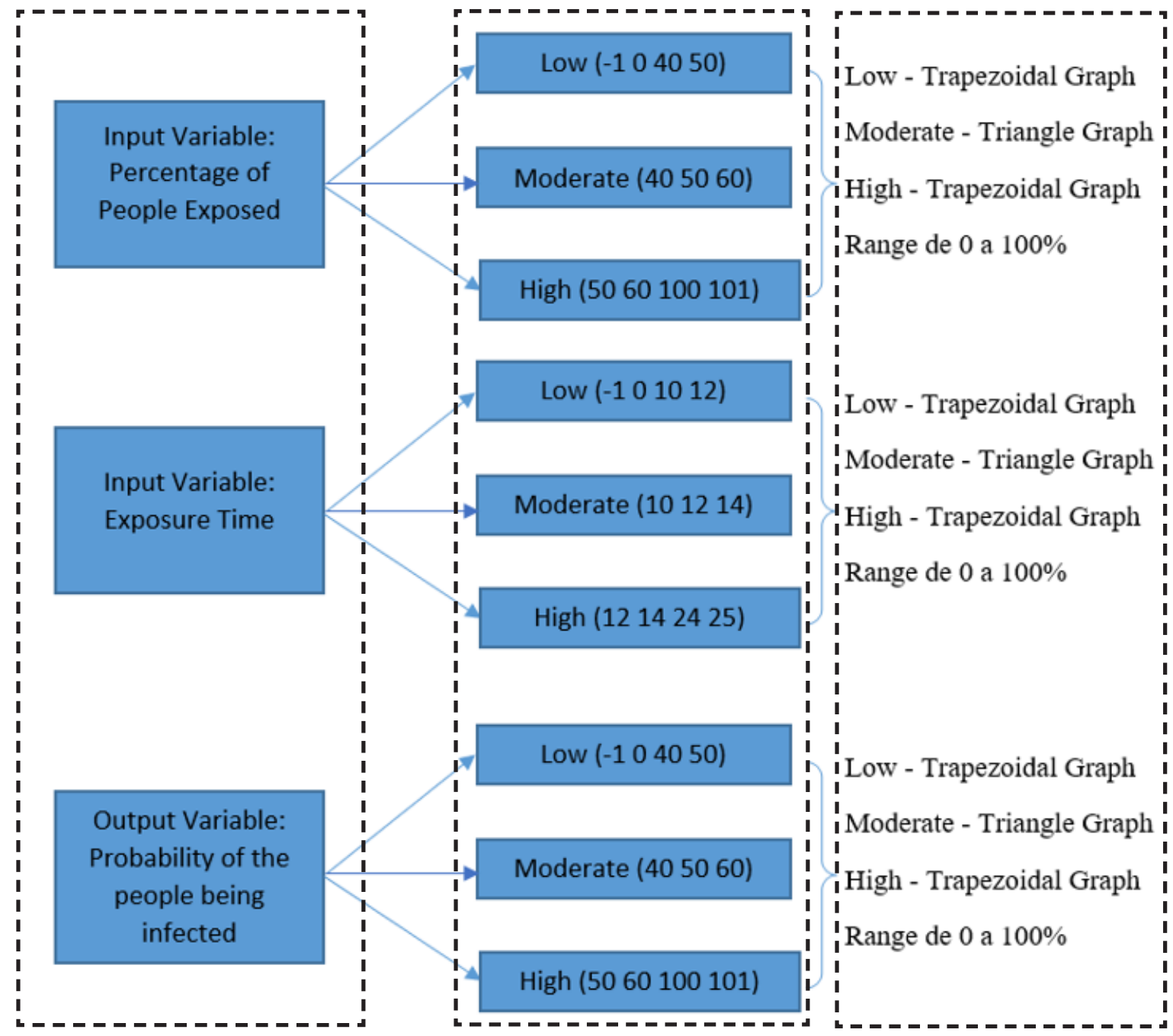

Subtitle: $1^{\circ}$ Dashed Square - Linguistic Variables $/ 2^{\circ}$ Dashed Square - Linguistic Terms $/ 3^{\circ}$ Dashed Square - Pertinence Functions

(b)

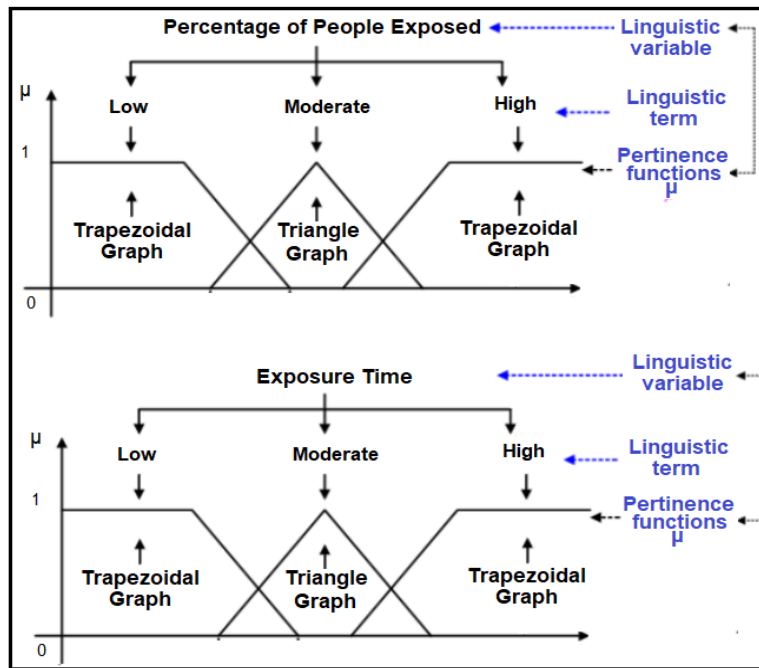

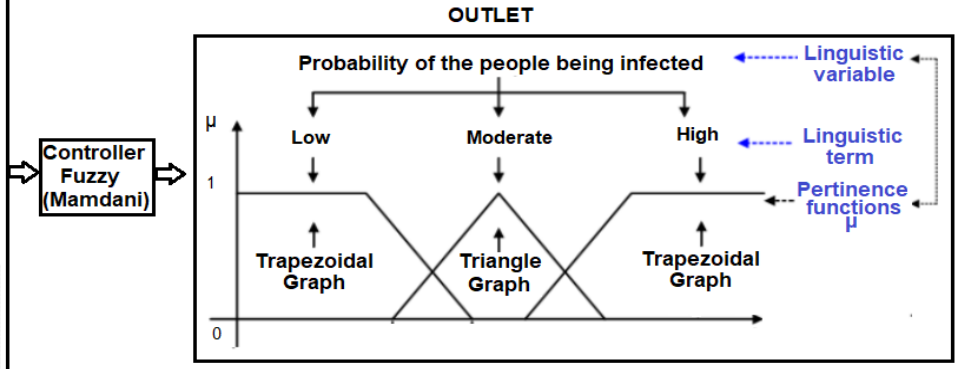


Besides the variables, rules are required, which have the duty to describe the behavior of the process. In the study, nine rules were used, the maximum number of possible rules. It is important to point out that it is not mandatory to use of the maximum number of rules in Fuzzy logic, in the study the decision to use this number was due to being a reasonable number of rules. Depending on the system, using the maximum number of rules may be impracticable due to its high complexity, in these cases the authors choose the most relevant rules. The rules created for the template are listed below:

-1st Rule: If the percentage of exposed people is low and the exposure time is low, then the probability of the person being infected is low;

- 2nd Rule: If the percentage of people exposed is low and the exposure time is moderate, then the probability of the person being infected is low;

-3rd Rule: If the percentage of exposed people is low and the exposure time is high, then the probability of the person being infected is low;

- 4th Rule: If the percentage of exposed people is moderate and the exposure time is low, then the probability of the person being infected is low;

- 5th Rule: If the percentage of exposed people is moderate and the exposure time is moderate, then the probability of the person being infected is moderate;

- 6th Rule: If the percentage of exposed people is moderate and the exposure time is high, then the probability of the person being infected is high;

- 7th Rule: If the percentage of exposed people is high and the exposure time is low, then the probability of the person being infected is moderate;

- 8th Rule: If the percentage of exposed people is high and the exposure time is moderate, then the probability of the person being infected is high;

- 9th Rule: If the percentage of exposed people is high and the exposure time is high, then the probability of the person being infected is high;

So that the program could generate the results, the Mamdani model was chosen and, in order to improve the quality of this research, the two main methods of defuzzification were applied, the centroid and the average of the maximums.

\section{RESULTS}

The Fuzzy logic modeling was executed based on epidemiologic bulletins released by the Brazilian Ministry of Health corresponding to the months of April and May and on information present on the Ministry of Health's webpage. 
(MINISTÉRIO DA SAÚDE (a, b, c, d), 2020).

By the simulation performed, the Fuzzy logic transmitted graphically the behavior if there was a population exposed to SARS-CoV-2 without isolation or any mean of prevention.

Figure 2: Fuzzy simulation of Sars-Cov-2 without isolation or protection: a) Method Centroide defuzzification and b) Method Mean of Maximum defuzzification

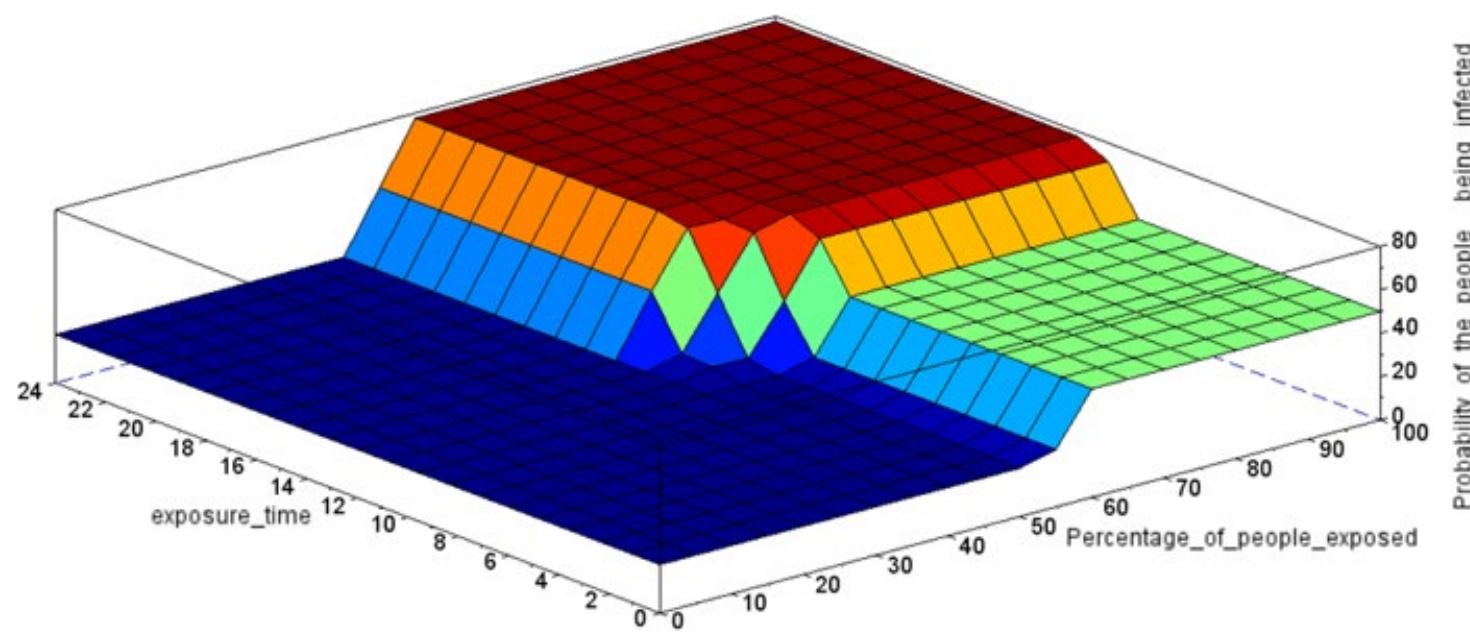

(a)

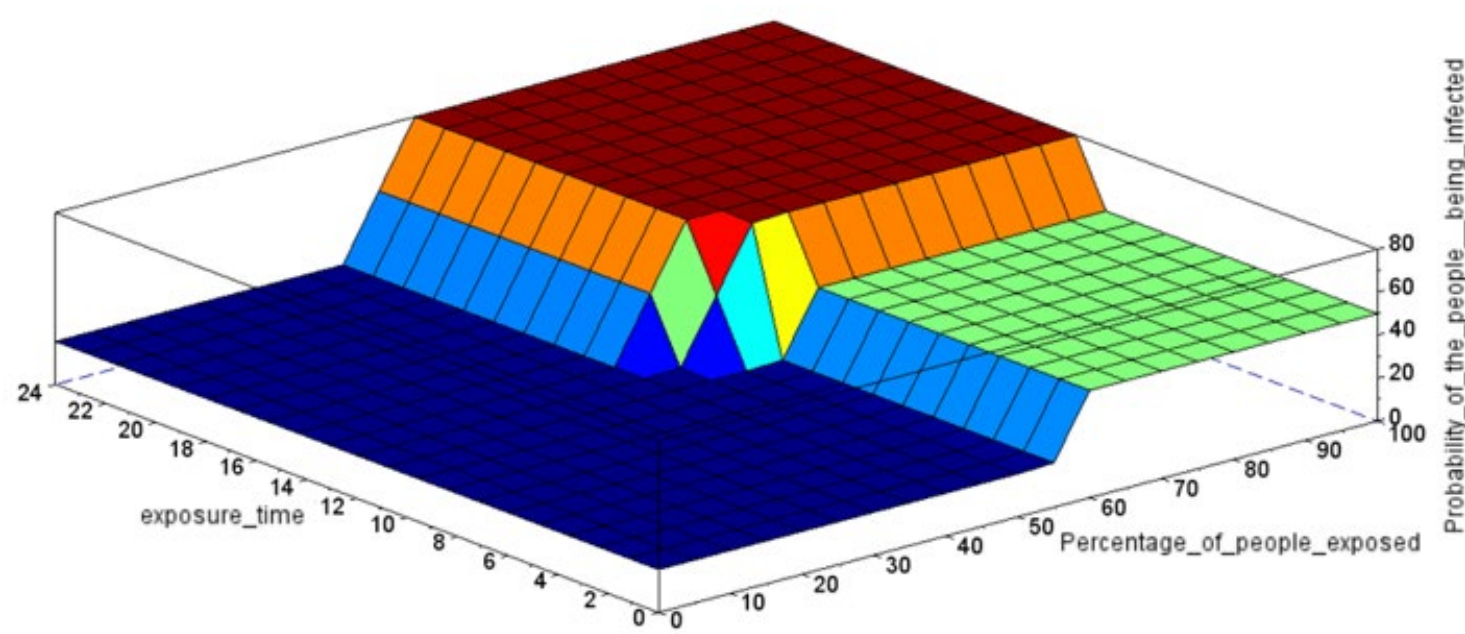

(b)

The Method Mean of Maximums transforms the fuzzy output into a discreet output by calculating the weighted arithmetic mean of the centers of gravity from the fuzzy sets which the element belongs, weighted by the area of the set (MATTOS; COELHO, 2015). It is clear that the two defuzzification methods are highly similar, as Malaman and Amorim (2017) informed the mean of maximums consists on a derivation of the center of gravity method and, therefore, their 
results are naturally similar, like the results found on this study where Figure 2 shows two nearly identical graphs. The authors decided to present both graph to demonstrate that any defuzzification method would have the same interpretation.

\section{DISCUSSION}

The 3D graph (Figure 2) demonstrates that when there is an increase in the percentage of exposed people alongside with the growth in exposure time, the probability of being infected is high; this condition is represented in the graph by the warm colors (yellow, orange and red), meanwhile the cold colors (dark blue and light blue) represent exactly the opposite, considering that the percentage of exposed people are low, even though the exposure time is high, the probability of being infected is low. However, if a high percentage of people are exposed, even with a low exposure time, the probability of being infected is moderate, due to the size of the exposed population. It may be noted by the figures that there were no big differences, demonstrating the reason why when the centroid method cannot be applied, the average of the maximums is usually the method of choice, having these few differences that are not enough for a change in the explanation.

According to Rodrigues and Santos (2004), the classic models, despite working well on simple and isolated phenomena, are not adequate to deal with contemporaneous problems and its complexities, interactions and human subjectivities. As fuzzy logic has the possibility to model complex problems with non-linear properties and is able to code knowledge similarly to how experts express the decision-making process, this logic contributes to improve the classic models. Furthermore, fuzzy logic makes the acquisition of knowledge easier, more reliable and less subjected to errors, besides being able to model systems involving multiple experts and to manipulate the uncertainties on a consistent and mathematic way (CLÁUDIO; MARTINS, 2011).

As fuzzy logic works with complex and uncertain modeling, it has the possibility to simulate different epidemiological scenarios, such as Lima, Santos and Nascimento (2015) study's, which they use fuzzy logic to assist medical diagnoses and epidemiology for the Corynebacterium gender. Another example is the Melo and Moraes (2018) study, which uses fuzzy logic to fundament decisions on the manage of dengue fighting. For this study, on which fuzzy logic was used on the SARS-CoV-2 scenario, it is possible to simulate different situations, with more or less intense isolations measures, it is also possible to improve this model, what may demonstrate different situations and scenarios through inserting new variables or changing the existing rules or changing the range, among other possible changes.

This result demonstrates that this technique can be an interesting and effective mean to provide information, since those who are utilizing the tool can effectively insert the logic and the set of rules which are fundamental for this software to work properly. 


\section{CONCLUSION}

The results were coherent and demonstrated graphically what would happen to a susceptible group if they were exposed without any mean of isolation or protection. The simulation proves to be a very important technique, because its possible to obtain general information through it, generating a critical view of different conditions without requiring a big amount of time to obtain answers. Simulation is a technique that greatly complements the reality of the situations. Therefore, being aware of what is expected will assist on making the appropriate choice of the software to be used.

\section{REFERENCES}

1. D.N. Prata, W. Rodrigues, P.H. Bermejo, Temperature significantly changes COVID-19 transmission in (sub)tropical cities of Brazil, Sci. Total Environ. 729 (2020) 138862. https://doi.org/10.1016/j.scitotenv.2020.138862.

2. Q. Bukhari, Y. Jameel, Will Coronavirus Pandemic Diminish by Summer?, SSRN Electron. J. (2020). https://doi.org/10.2139/ssrn.3556998.

3. D.G. de S. Rignel, G.P. Chenci, C.A. Lucas, Uma Introdução á Lógica Fuzzy, RRevista Eletrônica de Sistemas de Informação e de Gestão Tecnológica. 1 (2011) 17-28. http://periodicos.unifacef.com.br/index.php/resiget/ article/view/153

4. A.A. Marro, A.M. de C. Souza, E.R. de S. Cavalcante, G.S. Bezerra, R. de O. Nunes, Lógica Fuzzy: Concepts and Applications, (2000) 23.

5. J.F. dos Santos, Sistema inteligente fuzzy para auxílio ao diagnóstico de níveis de risco da gestação integrado à plataforma de telemedicina preneonatal, (2015) 97.

6. F.A.C. Gomide, R.R. Gudwin, R. Tanscheit, Fundamental concepts of fuzzy set theory, fuzzy logic and applications, Proc. 6 Th IFSA Congr. (1995) 1-38.

7. L.M. da Silva, Modelagem fuzzy como subsídios para a espacialização da vulnerabilidade costeira à erosão, (2013) 167. 
8. R.T. Fernandes, Supervisão de um sistema híbrido eólico/diesel usando lógica fuzzy, (2005) 118 .http:// www.cbc.ufms.br/tedesimplificado/tde_busca/arquivo.php?codArquivo=15.

9. D.C. de Melo, Implementação do sistema fuzzy de mamdani usando como ferramenta o Visual Basic for Application No Excel, Ibmec. (2009) 73. http://livros01.livrosgratis.com.br/cp112383.pdf.

10. S. de Lima, Implementation of Control Strategies Using Fuzzy Logic and Vector Control Techniques in a Finite Element Software, (2016) 221.

11. R.L. de S. Santos, A Comparative Study among Approaches based in Fuzzy Systems and Artificial Neural Networks to Estimate Importance of Comments about Products and Services, Federal University of Piaui, (2017) 20.

12. L.O. Gavião, G. Brito, A. Lima, Sustainability Indicators For Basic Education By Fuzzy Modeling, Sustainability Indicators For Basic Education By Model. Fuzzy. 19 (2015) 274-297. https://doi.org/10.5902/2236117015416,

13. C.S. Malaman, A. Amorim, Method for determining values in real estate appraisal: Comparing between linear regression model and fuzzy logic, Bol. Ciencias Geod. 23 (2017) 87-100. https://doi.org/10.1590/s198221702017000100006

14. W. Van Leekwijck, E.E. Kerre, Defuzziÿcation: criteria and classiÿcation, Fuzzy Sets Syst. 108 (1999) 159-178. https://doi.org/10.1016/S0165-0114(97)00337-0.

15. S.A. Sarkodie, P.A. Owusu, Investigating the cases of novel coronavirus disease (COVID-19) in China using dynamic statistical techniques, Heliyon. 6 (2020) and03747. https://doi.org/10.1016/j.heliyon.2020.e03747.

16. L. R. Alvarenga. Modelagem de epidemias através de modelos baseados em indivíduos. (2008) 130.

17. A. V. Farias. Um estudo da modelagem epidemiológica SIR usando conceitos de derivadas de ordem inteira e fracionária. (2017) 77.

18. S. L. Alvim, R. O. Nau, O. A. G. Oliveira. Lógica fuzzy : abordagem conceitual aplicada à logística de 
distribuição: indústria eletrônica, área de computadores, no Brasil. IV CONEP Congresso Online de Engenharia de Produção (2019) 2.

19. N. R. S. Ortega. Aplicação da teoria de conjuntos fuzzy a problemas da biomedicina. (2001) 166.

20. E. Araujo. Lógica Difusa ( Fuzzy ) e Raciocínio Aproximado : Conceitos e Aplicações. (2009) 16.

21. Ministério da Saúde (a). Coronavirus panel. Portal Of. ministry of health. (2020) Available in: HTTPS:// COVID.SAUDE.GOV.BR/ URL Accessed on: Accessed from April 26 to May 30 of 2020.

22. Ministério da Saúde (b). Boletim Epidemiológico 01: Infecção Humana pelo Novo Coronavírus (2019nCoV). COE 01, (2020) 17. Available in: https://www.saude.gov.br/images/pdf/2020/fevereiro/04/Boletim-epidemiologico-SVS-04fev20.pdf Accessed on: April 26th of 2020.

23. Secretária de Atenção Primária a Saúde (SAPS). Protocolo de Manejo Clínico do Coronavírus (COVID-19) na Atenção Primária à Saúde. Versão 7, (2020) 38. Available in: https://saude.rs.gov.br/upload/arquivos/202004/ 14140606-4-ms-protocolomanejo-aps-ver07abril.pdf Accessed on: April 26th of 2020.

24. Ministério da Saúde. Boletim Epidemiológico 15 (c): COE-COVID 15 , (2020) 68. Available in: https:// portalarquivos.saude.gov.br/images/pdf/2020/May/09/2020-05-06-BEE15-Boletim-do-COE.pdf Accessed on: May 10th of 2020.

25. Ministério da Saúde. Boletim Epidemiológico 16 (d): COE-COVID 16, (2020) 67. Available in: https://portalarquivos.saude.gov.br/images/pdf/2020/May/21/2020-05-19---BEE16---Boletim-do-COE-13h.pdf Accessed on: May 30th of 2020.

26. A. Cláudio, M. Martins. FUZZYCOM - componente de lógica fuzzy. (2011) 15.

27. G. D. A. Lima, E. A. dos Santos, S. P. Nascimento. Diagnostico medico e epidemiologia fuzzy para o gênero Corynebacterium. (2012) 6. 
28. J. C. da S. Melo, R. M. de Moraes. Sistema Espacial de Suporte à Decisão para Gestão do Combate ao Dengue Usando Lógica Fuzzy. TEMA (São Carlos), v. 19, n. 3, p. 405, (2018). DOI: 10.5540/tema.2018.019.03.405

29. F. Z. Rodrigues, S. A. Santos. A lógica fuzzy na administração de empresas. (2004) 12.

30. V. L. D MATTOS, L. C. COELHO. Propriedades de controladores fuzzy: um estudo de caso. Scientia Plena, v. 11, n. 8, p. 8, (2015). DOI: 10.14808/sci.plena.2015.081306

\section{APPENDIX}

Figure 3: Input pertinence graph, from Fuzzy logic.

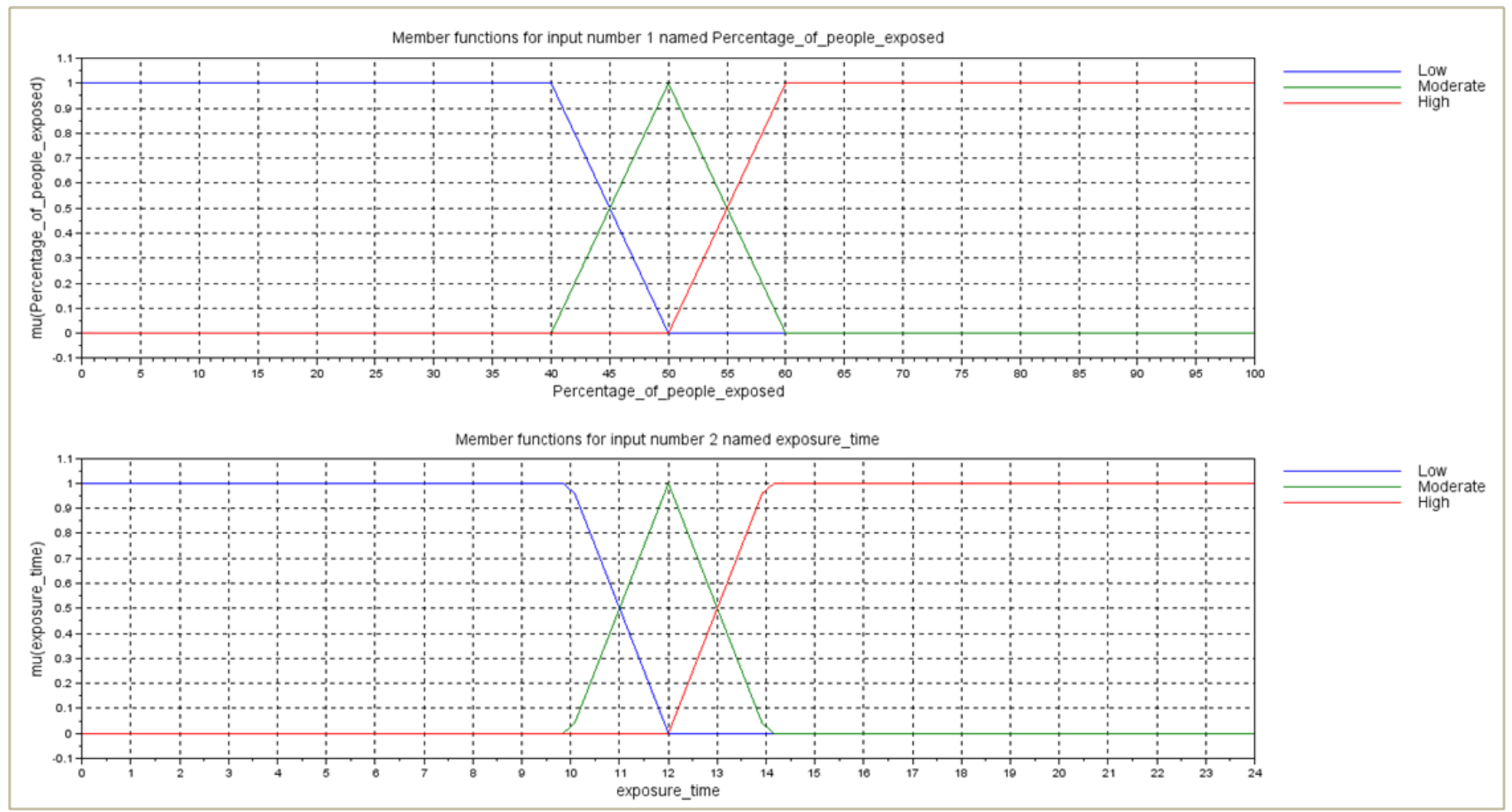


Figure 4: Output pertinence graph, from Fuzzy logic.

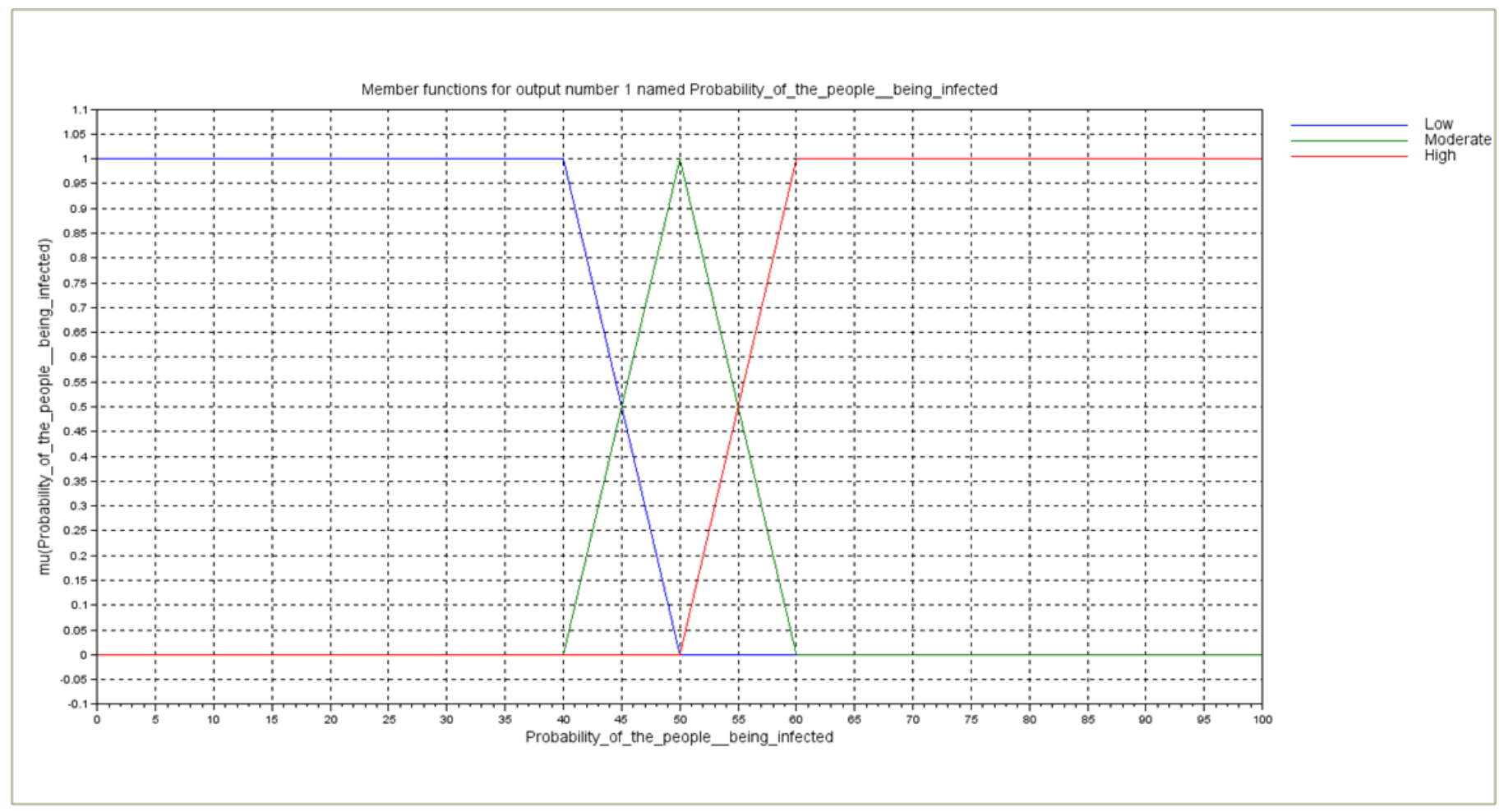

